Journal of Agricultural Sciences
(Tarim Bilimleri Dergisi)

\title{
Vigour Assessment of Dill (Anethum graveolens L.) Seed Lots in Relation to Predicting Seedling Emergence Potential
}

\author{
Eren OZDEN $^{a} \mathbb{D}^{\mathbb{D}}$, Nurcan MEMIS ${ }^{\mathrm{b}} \mathbb{D}^{\mathbb{D}}$, Burcu Begum KENANOGLU ${ }^{\mathrm{D}}$, Ibrahim DEMIR ${ }^{\mathrm{b}}$

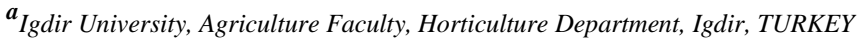

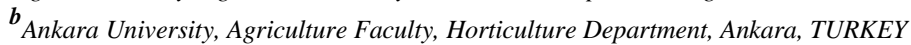

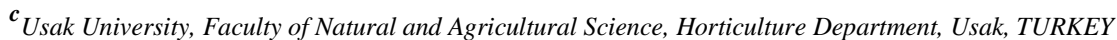

ARTICLE INFO

Research Article

Corresponding Author: Eren OZDEN, E-mail: eren.ozden@igdir.edu.tr

Received: 14 June 2019 / Revised: 13 September 2019 / Accepted: 23 September 2019 / Online: 18 January 2021

\section{ABSTRACT}

The study aimed to test various vigour tests to correlate them with seedling emergence in two field sowing dates and two different sowing depths in controlled room emergence of ten dill seed lots. Mean germination time, accelerated aging; for 24 hours, 48 hours, and 72 hours, electrical conductivity readings at 16 hours and 24 hours, and EC readings after AA test were used as vigour tests, and results were correlated with seedling emergence percentages. Seedling emergence was tested in two sowing dates in the field and two different sowing depths in controlled room conditions. Controlled room seedling emergence values $(80-95 \%$ in $2 \mathrm{~cm}, 76-92 \%$ in $4 \mathrm{~cm})$ were higher than those of field emergence values $(67-85 \%$ in the first sowing and $60-80 \%$ in the second sowing). Most of the vigour tests were significantly correlated with emergence potential. The highest correlation values were observed in EC16h and EC24h tests, significance between emergence and these two vigour tests were at $\mathrm{P}<0.001$ three out of four sowings. The results indicated that EC16h can be a fast, practical and easy method of seed vigour discrimination in dill seed lots.

Keywords: Accelerated aging, Electrical conductivity, Emergence correlations, Radicle emergence test, Seed vigour

(C) Ankara University, Faculty of Agriculture

\section{Introduction}

High seedling establishment is essential for crop production to be profitable, and it is therefore widely accepted as a critically important trait for farmers. Seed lots having similar standard germination percentages can perform differently under the stressful conditions of commercial crop production. Seed vigour gives further information of any lot in the sowing conditions and is described as the sum total of those properties of the seed that determine the potential level of activity and performance of the seed during germination and seedling emergence (Marcos-Filho 2015).

Seed vigour and poor performance under field environments influence not only the number of seedlings that emerge in crops, but also the uniformity of emergence. For small-seeded vegetable crops, unpredictable timing of seedling emergence can disrupt planned schedules of production such as with dill, and insufficient and slow emergence can result in poor uniformity and yield (Finch-Savage 1995). Dill is a small seeded, leafy, short season vegetable crop species. It is grown throughout the year in the Mediterranean region either open-field or under plastic tunnels. Sowing in various field environments reduces the emergence of dill seeds, and stand establishment may not always be successful (Ozden et al. 2017). This is common, particularly when an aged seed lot is used. Therefore, the estimation of emergence potential of any lot (vigour assessment) helps farmers to plan sowing times and helps seed companies to arrange seed marketing. Seed lots differing in vigour (emergence potential) can be identified in various vigour tests, such as accelerated aging (AA) (TeKrony 2003; Guloksuz \& Demir 2012), controlled deterioration (CD) (Basak et al. 2006), electrical conductivity (EC) (Matthews \& Powell 2006; Demir et al. 2019; Ozden et al. 2020), mean germination time (MGT) and radicle emergence tests (RE) (Matthews \& Powell 2011; Lv et al. 2016; Demir et al. 2019; Ozden et al. 2020). The tests have been shown to estimate the relative emergence of seed lots of many crops in the field and transplant modules. However, there is no study, to the best of our knowledge, on dill seeds. The objective of the present study was to investigate AA, EC, EC after AA and MGT as vigour tests to rank the relative emergence of seed lots of dill in field and controlled room conditions.

\section{Material and Methods}

Ten seed lots of dill (Anethum graveolens L. cv., Turkish dereotu) were obtained from commercial seed companies. The seed moisture content was determined according to ISTA (2017) rules. Seed lots were in sealed aluminium foil packets and were 
stored at $5{ }^{\circ} \mathrm{C}$ until use. Before seed vigour tests, germination tests were carried out at $20{ }^{\circ} \mathrm{C}$, for which 50 seeds of each lot were placed between paper towels (Filtrak, Germany) $(20 \mathrm{~cm} \mathrm{x} 20 \mathrm{~cm}$ ), and wetted with $10 \mathrm{~mL}$ of distilled water. The germination tests were conducted with four replicates of 50 seeds in the dark. The paper towels were rolled and placed in plastic bags to prevent water loss. Radicle emergence $(2 \mathrm{~mm})$ percentages were calculated in daily counts during the germination test. Normal seedling percentages in the final count, at 14 days after the beginning of the test, were considered as standard germination (SG).

The MGT was calculated based on frequent radicle emergence counts using the formula;

$\mathrm{MGT}=\sum \mathrm{n} . \mathrm{t} / \sum \mathrm{n}$

Where $\mathrm{n}=$ number of seeds newly germinated $(2 \mathrm{~mm}$ radicle emerged $)$ at time $\mathrm{t} ; \mathrm{t}=$ days from planting, $\sum \mathrm{n}=$ final germination

For the AA test, $40 \mathrm{~mL}$ of distilled water was added to each plastic aging box $(11 \times 11 \times 4 \mathrm{~cm})$ and 300 seeds were placed on a monolayer cheese cloth placed on the wire mesh tray $(10 x 10 x 3 \mathrm{~cm})$ inside the box (Hampton \& TeKrony 1995). Seeds were aged at $45^{\circ} \mathrm{C}$ for 24,48 and 72 hours, after which they were dried on a laboratory bench for about three hours. The SG test was then conducted with four replicates of 50 seeds, using normal seedling development for assessment (ISTA 2017). The remaining 100 seeds in each period were used for EC measurements (EC after AA) after ageing.

In the EC measurements, two replicates of 50 unaged (EC) and aged (EC after AA) seeds were weighed and soaked in 40 $\mathrm{mL}$ distilled water for 24 hours at $20^{\circ} \mathrm{C}$ in the dark. The $\mathrm{EC}$ of dill seeds were measured at 16 and 24 hours in both unaged (EC) seeds and seeds after accelerated aging (EC after AA). The EC of seed soak water was measured using a conductivity meter (Schott-Gerate $\mathrm{GmbH}$, Hofheim) and expressed as $\mu \mathrm{Scm}^{-1} \mathrm{~g}^{-1}$.

For controlled room emergence test (CRE), seeds (four replicates of 50 seeds/lot) were sown in 2 and $4 \mathrm{~cm}$ depths in peat moss (Plantaflor-Humus, Verkaufs-GmBH, Germany) in seedling trays $(32 \times 20 \times 6 \mathrm{~cm})$ and placed in the incubator at $20 \pm 2{ }^{\circ} \mathrm{C}$. Light was provided at seedling level by cool fluorescent lamps $\left(72 \mu \mathrm{Mm}^{-2} \mathrm{~s}^{-1}\right)$ for 16 hours a day. The relative humidity in the cabinet was kept over $70 \%$ in order to eliminate evaporation from the surface. The number of emerged seedlings (unfolding cotyledons on the surface) was counted daily up to 25 days, and percentages of normally developed seedling were calculated.

For the field emergence test (FE), the seeds (four replicates of 100 seeds/lot) were sown in the experimental field of the Department of Horticulture, Faculty of Agriculture, University of Ankara, Turkey, on 9 September 2017 (first sowing) and 29 September 2017 (second sowing). The soil was a sandy loam (pH: 7.57, N: 0.09, $\mathrm{P}_{2} \mathrm{O}_{5}: 5.5 \%, \mathrm{~K}: 0.16 \%, \mathrm{Na}: 0.41 \%$, Ca: 6.7\%, organic matter: $1.1 \%$ ). Daily minimum and maximum soil temperatures were recorded throughout both sowings and varied between 13 and $34^{\circ} \mathrm{C}$. The number of seedlings assessed to have emerged when the cotyledons had unfolded above the surface was counted daily for 35 days.

Statistical analysis was conducted using the Statistical Package for Social Sciences (SPSS) by using analyses of variance. Mean separation was made at the $5 \%$ level by the Duncan multiple range test. Correlation coefficients (r) of vigour tests with seedling emergence performance in controlled room and field conditions were also calculated.

\section{Results and Discussion}

The initial normal germination percentages of 10 seed lots were all above 90\% (Table 1). MGT ranged between 3.5 and 4.7 days. Some of the seed lots that had the same normal germination showed differences in MGT. For example, lots 6 and 9 had a $91 \%$ germination value but MGT values were 3.7 and 4.7 days respectively.

The AA produced a wide range of normal germination percentages amongst the seed lots, indicating considerable differences in seed vigour (Table 1). The smallest range was observed in the 24 hours ageing period in which the lowest and the highest germination percentages after aging were 67 and $89 \%$. These values were 37 and $70 \%$ at 48 hours of aging and 29 and $58 \%$ at 72 hours of aging. As the duration of the test increased, the germination speed between the lots also increased. There was a gradual decrease in the MGT of all lots as the AA period increased, and the lowest values were observed at 72 hours of aging. 
Table 1- Standard germination (normal germination), mean germination time (MGT, h), Accelerated ageing after 24h (AA24 h), 48h (AA48h) and 72 (AA72h) hours of 10 commercially available dill seed lots. Means with different letters in the same column denote significant difference at $5 \%$ level

\begin{tabular}{llllll}
\hline Seed lots & $S G(\%)$ & MGT (day) & $A A 24 h$ & $A A 48 h$ & $A A 72 h$ \\
\hline 1 & $96 \mathrm{a}$ & $4.0 \mathrm{c}$ & $89 \mathrm{a}$ & $70 \mathrm{a}$ & $58 \mathrm{a}$ \\
2 & $96 \mathrm{a}$ & $4.1 \mathrm{c}$ & $80 \mathrm{~b}$ & $62 \mathrm{~b}$ & $53 \mathrm{~b}$ \\
3 & $95 \mathrm{ab}$ & $3.9 \mathrm{bc}$ & $79 \mathrm{~b}$ & $56 \mathrm{c}$ & $50 \mathrm{c}$ \\
4 & $93 \mathrm{bc}$ & $3.5 \mathrm{a}$ & $72 \mathrm{c}$ & $50 \mathrm{de}$ & $35 \mathrm{f}$ \\
5 & $94 \mathrm{ab}$ & $3.7 \mathrm{ab}$ & $73 \mathrm{c}$ & $45 \mathrm{f}$ & $29 \mathrm{i}$ \\
6 & $91 \mathrm{~cd}$ & $3.7 \mathrm{ab}$ & $70 \mathrm{~cd}$ & $51 \mathrm{~d}$ & $46 \mathrm{~d}$ \\
7 & $90 \mathrm{~d}$ & $3.7 \mathrm{ab}$ & $70 \mathrm{~cd}$ & $47 \mathrm{ef}$ & $30 \mathrm{hi}$ \\
8 & $90 \mathrm{~d}$ & $4.5 \mathrm{~d}$ & $67 \mathrm{~d}$ & $37 \mathrm{~g}$ & $40 \mathrm{e}$ \\
9 & $91 \mathrm{~cd}$ & $4.7 \mathrm{~d}$ & $67 \mathrm{~d}$ & $50 \mathrm{de}$ & $33 \mathrm{fg}$ \\
10 & $90 \mathrm{~d}$ & $4.6 \mathrm{~d}$ & $70 \mathrm{~cd}$ & $51 \mathrm{~d}$ & $32 \mathrm{gh}$ \\
\hline Range & $90-96$ & $3.5-4.7$ & $67-89$ & $37-70$ & $29-58$ \\
\hline
\end{tabular}

The EC of soaking water after 16 hours (EC16h) and 24 hours (EC24h) were more contrasted between lots than were standard germination percentages, which ranged from 515 and 813 at 16 hours, and 521 and 883 at 24 hours (Table 2). EC measurements after accelerated aging increased as the aging time increased. The rate of EC increase was not the same in all seed lots. The EC readings of low-vigour seed lots such as lot 9 and 10 were higher than those of the high-vigour lots.

Table 2- Changes in EC after 16 (EC16h) and 24 hours (EC24h) and EC16, EC24h after Accelerated ageing after 24h and 48h in 10 dill seed lots. Means with different letters in the same column denote significant difference at $5 \%$ level

\begin{tabular}{lcccccccc}
\hline Seed lots & $E C 16 \mathrm{~h}$ & $E C 24 \mathrm{~h}$ & $\begin{array}{c}E C 16 \mathrm{~h} \\
/ A A 24 \mathrm{~h}\end{array}$ & $\begin{array}{c}E C 24 \mathrm{~h} \\
/ A A 24 \mathrm{~h}\end{array}$ & $\begin{array}{c}E C 16 \mathrm{~h} \\
/ A A 48 \mathrm{~h}\end{array}$ & $\begin{array}{c}E C 24 \mathrm{~h} / \\
A A 48 h\end{array}$ & $\begin{array}{c}E C 16 h / \\
A A 72 h\end{array}$ & $\begin{array}{c}E C 24 h / \\
A A 24 h\end{array}$ \\
\hline 1 & $515 \mathrm{a}$ & $521 \mathrm{a}$ & $565 \mathrm{a}$ & $576 \mathrm{a}$ & $547 \mathrm{a}$ & $561 \mathrm{a}$ & $621 \mathrm{a}$ & $636 \mathrm{a}$ \\
2 & $552 \mathrm{~b}$ & $600 \mathrm{~b}$ & $603 \mathrm{~b}$ & $618 \mathrm{~b}$ & $662 \mathrm{~b}$ & $661 \mathrm{~b}$ & $650 \mathrm{~b}$ & $670 \mathrm{~b}$ \\
3 & $626 \mathrm{c}$ & $655 \mathrm{c}$ & $684 \mathrm{~d}$ & $731 \mathrm{~d}$ & $757 \mathrm{e}$ & $763 \mathrm{e}$ & $767 \mathrm{~d}$ & $799 \mathrm{de}$ \\
4 & $700 \mathrm{e}$ & $698 \mathrm{~d}$ & $690 \mathrm{de}$ & $702 \mathrm{c}$ & $697 \mathrm{c}$ & $716 \mathrm{~d}$ & $749 \mathrm{~d}$ & $813 \mathrm{ef}$ \\
5 & $647 \mathrm{c}$ & $711 \mathrm{~d}$ & $634 \mathrm{c}$ & $691 \mathrm{c}$ & $708 \mathrm{~cd}$ & $691 \mathrm{c}$ & $747 \mathrm{~d}$ & $790 \mathrm{~d}$ \\
6 & $654 \mathrm{~cd}$ & $712 \mathrm{~d}$ & $710 \mathrm{e}$ & $731 \mathrm{~d}$ & $719 \mathrm{~d}$ & $721 \mathrm{~d}$ & $716 \mathrm{c}$ & $760 \mathrm{c}$ \\
7 & $691 \mathrm{e}$ & $692 \mathrm{~d}$ & $751 \mathrm{f}$ & $757 \mathrm{e}$ & $777 \mathrm{f}$ & $819 \mathrm{f}$ & $823 \mathrm{e}$ & $838 \mathrm{~g}$ \\
8 & $679 \mathrm{de}$ & $706 \mathrm{~d}$ & $742 \mathrm{f}$ & $810 \mathrm{f}$ & $792 \mathrm{f}$ & $825 \mathrm{f}$ & $805 \mathrm{e}$ & $830 \mathrm{fg}$ \\
9 & $756 \mathrm{f}$ & $751 \mathrm{e}$ & $786 \mathrm{~g}$ & $833 \mathrm{f}$ & $878 \mathrm{~g}$ & $896 \mathrm{~g}$ & $811 \mathrm{e}$ & $864 \mathrm{~h}$ \\
10 & $814 \mathrm{~g}$ & $884 \mathrm{f}$ & $885 \mathrm{~h}$ & $946 \mathrm{~g}$ & $990 \mathrm{~h}$ & $1024 \mathrm{~h}$ & $972 \mathrm{f}$ & $1005 \mathrm{i}$ \\
\hline Range & $515-813$ & $521-883$ & $565-884$ & $576-946$ & $547-989$ & $561-1024$ & $621-972$ & $636-1005$ \\
\hline
\end{tabular}

Seedling emergence in sowings at $2 \mathrm{~cm}$ and $4 \mathrm{~cm}$ depths in a controlled room ranged between 80 and $95 \%$ at the first sowing depth and between 76 and $92 \%$ at the second sowing depth (Table 3). Nine out of ten lots showed lower emergence percentages at deep sowing than at surface sowing depth. The differences between the two different sowing depths among the lots went up to $8 \%$ (Lots 4 and 6). Deep sowing was more discriminative of the seed vigour level of the lots, indicating the effect of mechanical stress on the vigour level. Field emergence percentages in the two sowings had very similar results, ranging between 67 and $85 \%$ in the first sowing, and between 60 and $80 \%$ in the second sowing. Most of the seed lots had the same or slightly lower emergence percentages in the two sowings. The differences varied only between 2 and $5 \%$ in nine lots. The final lot (lot 10) had a $7 \%$ difference between the two sowings. 
Table 3- Changes in controlled room conditions in $2 \mathrm{~cm}$ and $4 \mathrm{~cm}$ depth sowings and field emergence percentages in two sowings of 10 dill seed lots. Means with different letters in the same column denote significant difference at $5 \%$ level

\begin{tabular}{lcccc}
\hline \multirow{2}{*}{ Seed lots } & \multicolumn{2}{c}{$\begin{array}{c}\text { CRE (\%) } \\
\text { (sowing depth, })\end{array}$} & \multicolumn{2}{c}{ FE (\%) } \\
\hline 1 & $2 \mathrm{~cm}$ & $4 \mathrm{~cm}$ & 1. Sowing & 2. Sowing \\
\cline { 2 - 5 } 2 & $95 \mathrm{a}$ & $92 \mathrm{a}$ & $85 \mathrm{a}$ & $80 \mathrm{a}$ \\
3 & $91 \mathrm{~b}$ & $92 \mathrm{a}$ & $78 \mathrm{~b}$ & $75 \mathrm{~b}$ \\
4 & $88 \mathrm{c}$ & $82 \mathrm{~b}$ & $75 \mathrm{c}$ & $72 \mathrm{~cd}$ \\
5 & $87 \mathrm{c}$ & $79 \mathrm{~cd}$ & $72 \mathrm{de}$ & $75 \mathrm{~b}$ \\
6 & $82 \mathrm{de}$ & $78 \mathrm{de}$ & $74 \mathrm{~cd}$ & $71 \mathrm{cde}$ \\
7 & $84 \mathrm{~d}$ & $76 \mathrm{e}$ & $71 \mathrm{e}$ & $73 \mathrm{bc}$ \\
8 & $84 \mathrm{~d}$ & $81 \mathrm{bc}$ & $73 \mathrm{cde}$ & $70 \mathrm{de}$ \\
9 & $87 \mathrm{c}$ & $80 \mathrm{bcd}$ & $67 \mathrm{f}$ & $69 \mathrm{e}$ \\
10 & $82 \mathrm{de}$ & $80 \mathrm{bcd}$ & $68 \mathrm{f}$ & $65 \mathrm{f}$ \\
\hline Range & $80 \mathrm{e}$ & $76 \mathrm{e}$ & $67 \mathrm{f}$ & $60 \mathrm{~g}$ \\
\hline
\end{tabular}

Correlation values between seed vigour tests and two sowings in CRE and two in field conditions indicated several close associations (Table 4). EC16h, EC24h and EC24h/AA24h were highly correlated $(\mathrm{P}<0.001)$ in three out of four sowings. The rest of the vigour tests showed various levels of correlation but not at that level (Table 4). SG had a low level of significance, with two at $5 \%$ and two at the $1 \%$ level along with AA72h (three at 0.05 , one at 0.01 ).

Table 4- Correlation coefficients calculated for MGT, AA (24, 48 and 72h), EC after 16h (EC16h), 24h (EC24h), EC16h after AA $24 \mathrm{~h}$ and $48 \mathrm{~h}$ and $72 \mathrm{~h}$ and standard laboratory germination (SG) as estimation of seedling emergence percentages of field emergence and controlled room conditions in 10 dill seed lots

\begin{tabular}{|c|c|c|c|c|c|c|c|}
\hline \multirow{2}{*}{ Seed Vigour Test } & \multicolumn{2}{|c|}{$\begin{array}{c}C R E \\
\text { (Sowing depth) }\end{array}$} & \multicolumn{2}{|c|}{$F E$} & \multicolumn{3}{|c|}{ Total } \\
\hline & $2 \mathrm{~cm}$ & $4 \mathrm{~cm}$ & 1. Sowing & 2. Sowing & $*$ & $* *$ & $* * *$ \\
\hline MGT & $-0,212$ & $-0,002$ & $-0,425$ & $-0.647 *$ & 1 & & \\
\hline AA24h & $0,831 * *$ & $0,820 * *$ & $0,951 * * *$ & $0.721 *$ & 1 & 2 & 1 \\
\hline AA48h & $0,685^{*}$ & $0,764 * *$ & $0,829 * *$ & 0.554 & 1 & 2 & \\
\hline AA72h & $0,860 * *$ & $0,744^{*}$ & $0,702 *$ & $0.678^{*}$ & 3 & 1 & \\
\hline EC16h & $-0.871 * * *$ & $-0.809 * *$ & $-0.890 * * *$ & $-0.897 * * *$ & & 1 & 3 \\
\hline $\mathrm{EC} 24 \mathrm{~h}$ & $-0,915 * * *$ & $-0,836 * *$ & $-0,880 * * *$ & $-0.922 * * *$ & & 1 & 3 \\
\hline EC16h/AA24h & $-0,785^{* *}$ & $-0,713^{*}$ & $-0,862 * *$ & $-0.923 * * *$ & 1 & 2 & 1 \\
\hline EC24h/AA24h & $-0,799 * *$ & $-0,731^{*}$ & $-0,887 * * *$ & $-0.958 * * *$ & 1 & 1 & 2 \\
\hline EC16h/AA48h & $-0,815^{* *}$ & $-0,664 *$ & $-0,852 * *$ & $-0.985^{* * *}$ & 1 & 2 & 1 \\
\hline EC24h/AA48h & $-0,774 * *$ & $-0,637^{*}$ & $-0,843 * *$ & $-0.969 * * *$ & 1 & 2 & 1 \\
\hline EC16h/AA72h & $-0,795 * *$ & $-0,708^{*}$ & $-0,799 * *$ & $-0.933 * * *$ & 1 & 2 & 1 \\
\hline EC24h/AA72h & $-0,838 * *$ & $-0,776^{* *}$ & $-0,842 * *$ & $-0.927 * * *$ & & 3 & 1 \\
\hline SG & $0.728^{*}$ & $0.743^{*}$ & $0.849^{* *}$ & $0.724 *$ & 3 & 1 & \\
\hline
\end{tabular}

$$
\text { *; } P<0.05, * * ; P<0.01, * * * ; P<0.001
$$

The close and significant relations between EC16 and four sowing times are shown in Figure 1. The relationship between $\mathrm{SG}$ and sowings are also given in the same figure. EC16h was highly related to CRE percentages $\left(R^{2}=0.761, \mathrm{P}<0.001\right.$, $\left.R^{2}=0.656, \mathrm{P}<0.01\right)$ and emergence in field conditions $\left(R^{2}=0.792-0.803, \mathrm{P}<0.001\right)$, while SG was related to emergence percentages at much lower levels of significance $\left(R^{2}=0.53-0.55\right.$ in $\mathrm{CRE} ; \mathrm{P}<0.05, R^{2}=0.52-0.72, \mathrm{P}<0.05-0.01$ in field sowings $)$.

The present study indicated that EC16 and EC24h were highly related to seedling emergence in controlled room and field conditions ( $\mathrm{P}<0.001,3$ out of 4 sowing dates) (Table 4). Field establishment of some vegetables such as dill is usually performed with direct sowing of the seeds. As a result, rapid and uniform emergence of vigorous seedlings of the desired lot is a key event in ensuring high plant performance, affecting uniformity of development yield and quality of the harvested product. The main necessity to achieve that is the use of high-vigour seed lots. Standard laboratory germination tests indicate the emergence potential of any seed lot when the sowing environment is favourable for emergence. However, estimation of field emergence potential (seed vigour) of any lot is necessary, since deviations in ideal sowing conditions are common in the field. These deviations from ideal conditions are becoming more common due to climatic changes in various parts of the world. Thus, sub-optimum sowing environments are common because of low water availability, adverse soil characteristics and management practices. The use of commercially available seed lots with more than $90 \%$ of standard laboratory germination ensured a realistic approach to test emergence potential, since seed vigour is defined as the quality parameter that discriminates the lots with high germination percentages (Marcos-Filho 2015). Despite SG values being very high, accelerated aging after 24, 48 and 72 hours showed a great range (Table 1). The range was extended as the seed aging period lengthened. 


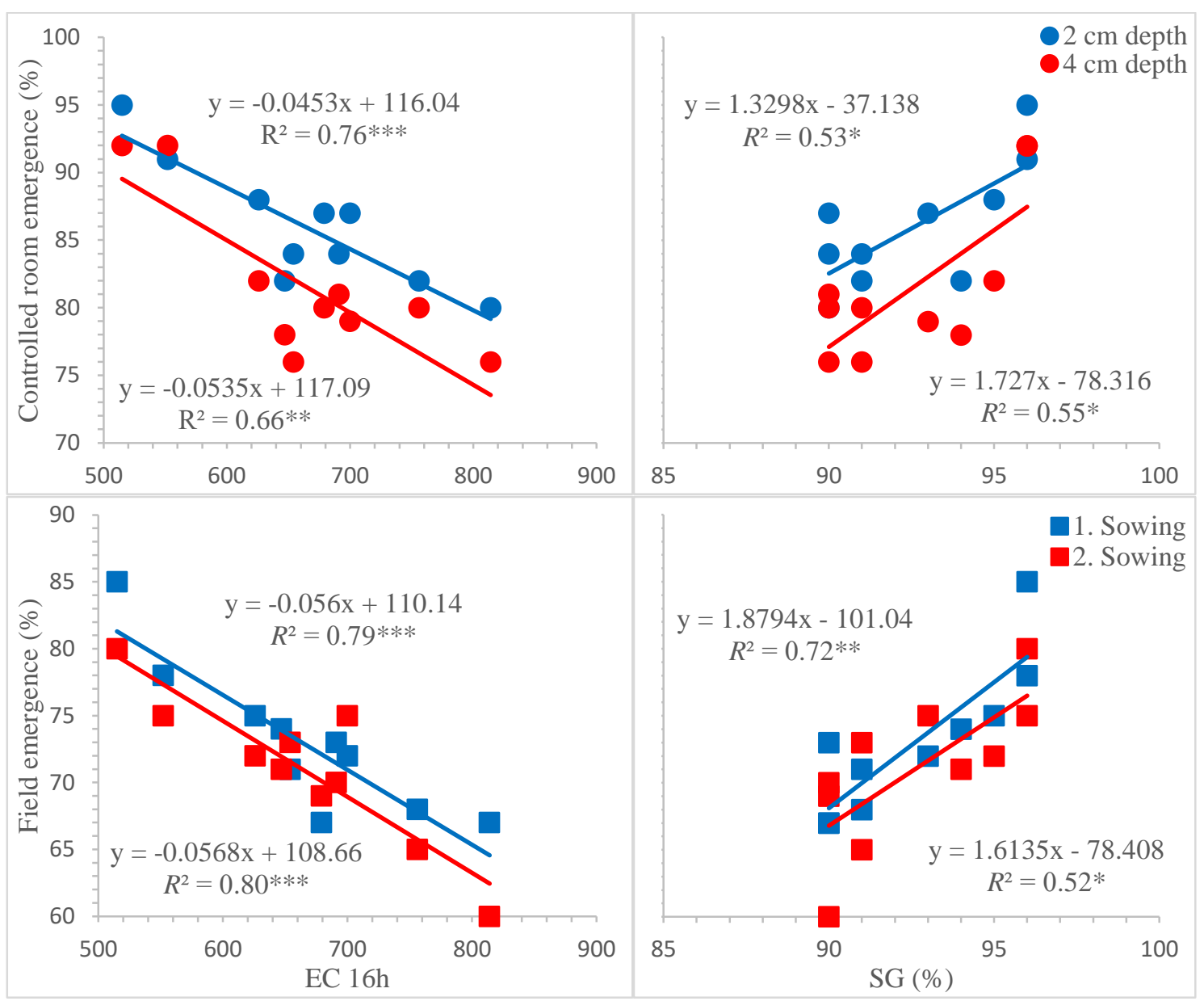

Figure 1- Relationship between electrical conductivity of $16 \mathrm{~h}$ (EC16h), and SG with field emergence in two sowings, 1. ( $\square$ ) and 2. sowing ( $\bullet$ ), and $2 \mathrm{~cm}(\bullet)$ and $4 \mathrm{~cm}(\bullet)$ depth sowings in controlled room emergence, of 10 dill seed lots.

Significance: *: $0.05, * *: 0.01, * * *: 0.001$

The most obvious physiological manifestation of seed aging is the decline in germination rate, which is associated with seedling size and abnormalities. The accelerated aging test and electrical conductivity are two vigour tests that are currently validated by ISTA rules (ISTA 2017) for soybeans and garden peas and beans respectively (ISTA 2017). There are a number of studies in which AA is well related to the seedling emergence of horticultural and agronomical plant seeds (TeKrony 2003; Marcos-Filho 2015). Seeds in the accelerated aging test are exposed to high relative humidity and high temperature (100\% RH, 40-45 ${ }^{\circ} \mathrm{C}$ ). About 24-72 hours is basically suggested to be used with large seeded plants. In our study, AA with three different aging periods was correlated to seedling emergence $(\mathrm{P}<0.05-\mathrm{P}<.001, \mathrm{r}=0.678-0.890)$ except in one case (AA48h, second sowing field emergence) (Table 4). This shows that the AA test can also be used with small seeded species. The reason that AA is less successful with small seeded plant seeds is that small seeds absorb water more rapidly, resulting in large variations and inequality among the seeds and lack of uniformity among the samples (Demir \& Mavi 2007; TeKrony 2003). It has been suggested that this difference among seed lots promotes large differences between aging rates and great reductions in germination after aging. We have not measured the seed moisture contents after aging. However, we spread the seeds on just a single layer of mesh in an aging box to expose the seeds to high relative humidity. One precaution in aging small seeded species is to prevent seeds from dropping into the water underneath the mesh tray. Therefore, we put a cheese cloth under the seeds to prevent that.

Mean germination times have been used to assess seed quality in agricultural species (Demir et al. 2008; Khajeh-Hosseini et al. 2009; Mavi et al. 2010). In this work MGT was significantly related in only one case (the second sowing in the field) but had a relatively lower correlation with seedling emergence percentages $\left(R^{2}=0.647, \mathrm{P}<0.05\right)$ compared to EC or AA tests (Table 4). MGT is generally calculated by frequent counts of germination, and MGT value extends as the delay between imbibition and radicle emergence. We suppose that more frequent counts during germination, particularly in the early stages of germination, would have given more discriminating results in MGT because seed lots in dill started to germinate in the very early hours of the test (12 hours). 
Electrical conductivity has been described as a biochemical vigour test and associates with low germinability to high release of solutes in soaking (McDonald 1999; Matthews \& Powell 2006; Demir et al. 2012; Ermis et al. 2016; Demir et al. 2019; Ozden et al. 2020). The principle of the EC test is that more deteriorated seeds release greater amount of solutes to the external environment. Under field conditions, leakage of exudates after sowing can stimulate the growth of pathogenic microorganisms and impair seedling emergence. Leakage during imbibition has been related to disruption of cell membrane systems and loss of semi-permeable structures (Matthews 1985). The negative correlation found between EC and seedling emergence (Figure 1) showed greater leakage in low-vigorous seeds. High solute leakage may result in an increase in the inoculum potential of various diseases such as Pythium, with dead tissue providing an initial site for infection (Matthews et al. 1988). The main advantage of using EC measurements as estimates of seed vigour level is the short time needed for assessment. This is particularly confirmed in this study for EC measurements just after 16 hours (overnight). The fast evaluation of seed vigour of the lots has great value for seed companies because in some periods of the year they need to test a large number of seed lots. Such tests save time, and are practical for farm based vigour assessments. Our results suggest that EC measurements can be used by seed producers to identify low-vigour lots.

\section{Conclusions}

In conclusion, we have shown that solute leakage from seeds using EC has the potential to predict seed vigour level in dill seeds. Higher levels of leakage were seen for dill lots that also showed low emergence not only in field (sub-optimum) conditions but also controlled room conditions indicating low vigour seeds. Differences among the lots can be detected within 16 hours (overnight) by EC readings. There may be a potential for a quick, cheap and simple vigour assessment method for testing seed vigour in farm-based tests.

\section{References}

Basak O, Demir I, Mavi K \& Matthews S (2006). Controlled deterioration test for predicting seedling emergence and longevity of pepper (Capsicum annuum L.) seed lots. Seed Science and Technology 34(3): 723-734. https://doi.org/10.15258/sst.2006.34.3.16

Demir I \& Mavi K (2007). Controlled deterioration and accelerated aging tests to predict seedling emergence of watermelon under stressful conditions and longevity. Seed Science and Technology 35(2): 445-459. https://doi.org/10.15258/sst.2007.35.2.19

Demir I, Ermis S, Mavi K \& Matthews S (2008). Mean germination time of pepper seed lots (Capsicum annuum L.) predicts size and uniformity of seedlings in germination tests. Seed Science and Technology 36(1): 21-30. https://doi.org/10.15258/sst.2008.36.1.02

Demir I, Cebeci C \& Guloksuz T (2012). Electrical conductivity measurements to predict germination of commercially available radish seed lots. Seed Science and Technology 40(2): 229-237. https://doi.org/10.15258/sst.2012.40.2.08

Demir I, Kenanoglu, B B \& Ozden E (2019). Seed vigour tests to estimate seedling emergence in cress (Lepidium sativum L.) seed lots. Not Bot Hortl Agrobo 47(3):881-886. https://doi.org/10.15835/nbha47311453

Ermis S, Kara F, Ozden E \& Demir I (2016). Solid matrix priming of cabbage seed lots: repair of ageing and increasing seed quality. Tarim Bilimleri Dergisi 22(4): 588-595. https://doi.org/10.1501/Tarimbil_0000001417

Finch-Savage W E (1995). Influence of seed quality on crop establishment, growth and yield. In: A.S. Basra (Ed.), Seed Quality. Basic Mechanisms and Agricultural Implications, Haworth Press, Inc., New York 45-80

Guloksuz T \& Demir I (2012). Vigor tests in geranium, salvia, gazania and impatiens seed lots to estimate seedling emergence potential in modules. Propagation of Ornamental Plants 12(3): 133-138

Hampton J G \& TeKrony D M (1995). Handbook of vigor test methods. The International Seed Testing Association, Zurich, Switzerland

ISTA (2017). International Rules for Seed Testing, International Seed Testing Association, Bassersdorf, Switzerland

Khajeh-Hosseini M, Lombholt A \& Matthews S (2009). Mean germination time in the laboratory estimates the relative vigour and field performance of commercial seed lots of maize (Zea mays L.). Seed Science and Technology 37: 446-456 https://doi.org/10.15258/sst.2009.37.2.17

Lv Y Y, Wang Y R \& Powell A A (2016). Frequent individual counts of radicle emergence and mean just germination time predict seed vigour of Avena sativa and Elymus nutans. Seed Science and Technology 44(1): 189-198. https://doi.org/10.15258/sst.2016.44.1.08

Marcos-Filho M (2015). Seed vigour testing: an overwiew of the past, present and future perspectives. Scientia Agricola 72(4): 363-374 http://dx.doi.org/10.1590/0103-9016-2015-0007

Matthews S (1985). Physiology of seed aging. Outlook on Agriculture 14(2): 89-94. https://doi.org/10.1177/003072708501400206

Matthews S \& Powell A A (2006). Electrical conductivity vigour test: physiological basis and use. Seed Testing International, 131: $32-35$

Matthews S \& Powell A A (2011). Towards automated single counts of radicle emergence to predict seed and seedling vigour. Seed Testing International 142: 44-48

Matthews S, Powell A A \& Spaeth S C (1988). Seedling vigour and susceptibility to disease and pests. In World Crops: Cool Season Food Legumes, (ed. R.J. Summerfield), 619-625, Kluwer Academic Publishers Group, The Netherlands

Mavi K, Demir I \& Matthews S (2010). Mean germination time estimates the relative emergence of seed lots of three cucurbit crops under stress conditions. Seed Science and Technology 38(1): 14-25. https://doi.org/10.15258/sst.2010.38.1.02

McDonald M B (1999). Seed deterioration: physiology, repair and assessment. Seed Science and Technology 27(1): 177-237

Ozden E, Ozel K, Kapcak D, Memis N \& Demir I (2017). The Effect of Priming Plus Vermicompost on Seed Quality and Seedling Performance of Dill (Anethum graveolens L.). In: Proceedings of the 1st International Congress on Medicinal and Aromatic Plants, 1012 May, Konya, Turkey, pp. 421-424

Ozden E, Memis N, Gokdas Z, Catikkas E \& Demir I (2020). Seed Vigour Evaluation of Rocket (Eruca sativa Mill.) Seed Lots. Journal of the Institute of Science and Technology, 10(3): 1486-1493. https://doi.org/ 10.21597/jist.713180

TeKrony D M (2003). Precision is an essential component in seed vigour testing. Seed Science and Technology 31(2): 435477. https://doi.org/10.15258/sst.2003.31.2.20 